\title{
Glucose estimation in the salivary secretion of diabetes mellitus patients
}

This article was published in the following Dove Press journal:

Diabetes, Metabolic Syndrome and Obesity:Targets and Therapy 6 July 2012

Number of times this article has been viewed

\author{
Panda Abikshyeet ${ }^{\prime}$ \\ Venkatapathy Ramesh ${ }^{2}$ \\ Nirima Oza ${ }^{2}$ \\ 'Department of Oral Pathology, \\ Kalinga Institute of Dental Sciences, \\ Kalinga Institute of Industrial \\ Technology University, Bhubaneswar, \\ Odisha, ${ }^{2}$ Department of Oral \\ Pathology and Microbiology, Mahatma \\ Gandhi Post Graduate Institute of \\ Dental Sciences, Puducherry, India
}

Correspondence: Panda Abikshyeet Department of Oral Pathology, Kalinga Institute of Dental Sciences, Campus 5, KIIT University, Bhubaneswar, 751024, Odisha, India $\mathrm{Tel}+919040324224$

Email abikshyeet@yahoo.com
Aim: Saliva is one of the most abundant secretions in the human body and its collection is easy and noninvasive. The aim of this study was to find a medium that can be used to diagnose and monitor diabetes. In this, saliva could play a major role. To substantiate the role of saliva as a diagnostic tool, we compared saliva samples with blood glucose and glycated hemoglobin $\left(\mathrm{HbA}_{1 \mathrm{c}}\right)$ in healthy and diabetic subjects.

Materials and methods: Included in the study were 106 patients, newly diagnosed with type 2 diabetes mellitus and 15 healthy control subjects. The patients and control subjects were asked to come to the clinic in the morning, after an 8-hour fast. At that time, $5 \mathrm{~mL}$ of venous blood was collected, $2 \mathrm{~mL}$ of which was collected in an ethylenediaminetetraacetic acid (EDTA)-containing blood collection tube and sent for $\mathrm{HbA}_{1 \mathrm{c}}$ estimation. Unstimulated saliva was collected from both groups as well. The saliva and sera from the blood samples were subjected to glucose estimation.

Results: The correlation coefficient between serum glucose and salivary glucose in the control group was calculated and the $r$ value was found to be 0.5216 , which was statistically significant $(P<0.05)$. The correlation coefficient between serum glucose and salivary glucose in the patient group was also calculated and the $r$ value was found to be 0.7686 , which was highly significant $(P<0.01)$. Finally, the correlation coefficient between $\mathrm{HbA}_{1 \mathrm{c}}$ level and salivary glucose in the patient group was calculated and the $r$ value was found to be 0.5662 , which was also highly significant $(P<0.01)$.

Keywords: saliva, salivary glucose, serum glucose, insulin, hyperglycemia

\section{Introduction}

Diabetes mellitus is a massive, growing, silent epidemic that has the potential to cripple health services in all parts of the world. Diabetes mellitus is a group of chronic diseases characterized by insulin deficiency, cellular resistance to insulin action, or both, resulting in hyperglycemia and other related metabolic disturbances. The disease is associated with serious complications of the eyes, kidneys, heart and blood vessels, and other organ systems, which may markedly impair quality of life and shorten the patient's lifespan. ${ }^{1}$ Many people are affected by diabetes worldwide and the number is climbing steeply. ${ }^{2}$ Currently, a diagnosis of diabetes is achieved by evaluating blood glucose levels. However, monitoring of glycated hemoglobin $\left(\mathrm{HbA}_{1 \mathrm{c}}\right)$ levels has become more common and frequent, providing an accurate measure of average glycemic control over the past three months. ${ }^{3,4}$ Monitoring blood glucose at frequent intervals causes unnecessary discomfort and mental trauma to patients; therefore, a much simpler and noninvasive technique for the diagnosis and monitoring of diabetes 
is very desirable..$^{5}$ The present study was conducted to determine the role of saliva as a diagnostic tool by correlating preprandial serum glucose and salivary glucose in the patient and control groups. To corroborate the glycemic control level with salivary glucose level, correlations between $\mathrm{HbA}_{1 \mathrm{c}}$ and salivary glucose in the patient group were also determined.

\section{Materials and methods}

Included in the study were 106 patients (52 males and 54 females) aged 36-65 years, who were newly diagnosed with non-insulin-dependent (type 2) diabetes mellitus and attended the diabetic clinic and the outpatient department of Mahatma Gandhi Postgraduate Institute of Dental Sciences, as well as 15 healthy control volunteer subjects (nine males and six females), aged 36-65 years. The patients were grouped into three age groups: 31 in group 1 (aged 36-45 years), 52 in group 2 (aged 46-55 years), and 23 in group 3 (aged 56-65 years). Subjects currently under treatment for diabetes, diagnosed with type 1 diabetes mellitus, with any other systemic diseases, or with tobacco or alcohol habits were excluded from the study. Written consent was obtained from each individual taking part in the study and a data sheet was completed detailing the person's name, age, sex, and relevant medical history. The patients and control subjects were asked to come into the clinic in the morning, on an empty stomach, after 8 hours of fasting; $5 \mathrm{~mL}$ venous blood was collected, $2 \mathrm{~mL}$ of which was collected in an ethylenediaminetetraacetic acid (EDTA)-containing blood collection tube and stored. The rest of the blood was collected in a sterilized glass test tube. The patients were asked to wash their mouths with tap water and to spit two or three times, after which they were told to spit the saliva pooled in their mouths for the following 10 minutes into the sterile sample collection container. The saliva and blood samples were centrifuged and glucose was estimated in the serum and supernatant saliva by the glucose oxidase-peroxidase method. Ninety-six patients were selected at random from the study group and their collected blood in the EDTA tubes was subjected to $\mathrm{HbA}_{1 \mathrm{c}}$-level estimation, using the ion exchange resin method.

Statistical analysis of the obtained data was conducted using WinSTAT ${ }^{\circledR}$ statistical software (v. 2007.1; R Fitch Software, Chicago, IL). Means and standard deviations (SDs) were calculated for the individual groups. These were then compared using Pearson's correlation coefficient, independent Student's $t$-test, Fisher's test, and regression coefficient. A $P$ value $<0.05$ was accepted as significant and a value $<0.01$ was considered highly significant.

\section{Results}

In the control group, the serum glucose levels ranged from 73.91 to $101.0 \mathrm{mg} / \mathrm{dL}$, with a mean of $86.82 \mathrm{mg} / \mathrm{dL}$ and SD of 9.46 . The salivary glucose levels ranged from 0.51 to $2.32 \mathrm{mg} / \mathrm{dL}$, with a mean of $1.23 \mathrm{mg} / \mathrm{dL}$ and SD of 0.52 . The correlation coefficient between serum glucose and salivary glucose was calculated and the $r$ value was found to be 0.5216 , which was statistically significant $(P<0.05)$.

In the patient group, the serum glucose ranged from 66.31 to $326.8 \mathrm{mg} / \mathrm{dL}$, with a mean of $154.70 \mathrm{mg} / \mathrm{dL}$ and $\mathrm{SD}$ of 60.85. The salivary glucose ranged from 0.31 to $18.16 \mathrm{mg} / \mathrm{dL}$, with a mean of $4.22 \mathrm{mg} / \mathrm{dL}$ and SD of 3.59. The correlation coefficient between serum glucose and salivary glucose was calculated and the $r$ value was found to be 0.7686 , which was highly significant $(P<0.01)$. It is worth noting that the significance of the study group was much greater than that of the control group.

The $\mathrm{HbA}_{1 \mathrm{c}}$ level ranged from $5.5 \%$ to $14.1 \%$, with a mean of $7.81 \%$ and SD of 1.65 . The correlation coefficient between $\mathrm{HbA}_{1 \mathrm{c}}$ level and salivary glucose was calculated and the $r$ value was found to be 0.5662 , which was highly significant $(P<0.01)$.

Comparisons of salivary glucose levels between the control and patient groups were performed with an independent $t$-test; a $t$-value of 3.21 was obtained and the difference was highly significant $(P<0.01)$, as shown in Table 1.

The patient group was divided into three subgroups depending upon their serum glucose level, as shown in Table 2. The salivary glucose levels of the three subgroups were compared using an $f$-test, and the difference was found to be highly significant $(P<0.01)$.

Similarly, the patient group was divided into three subgroups according to their $\mathrm{HbA}_{1 \mathrm{c}}$ percentage, as shown in Table. 3. The salivary glucose levels of the three subgroups were again compared using an $f$-test and the difference found was highly significant $(P<0.01)$.

No significant differences were found $(P>0.05)$ in comparing salivary glucose levels across different

Table I Comparison of preprandial salivary glucose between control and patient groups

\begin{tabular}{llll}
\hline Group & Mean & SD & t-value \\
\hline Control & $1.23 \mathrm{mg} / \mathrm{dL}$ & 0.52 & $\left.3.2\right|^{* *}$ \\
Patient & $4.22 \mathrm{mg} / \mathrm{dL}$ & 3.59 & $(P<0.0 \mathrm{I})$ \\
\hline
\end{tabular}

Note: $*_{t}$-value shows statistically significant difference between patient and control. Abbreviation: SD, standard deviation. 
Table 2 Comparison of preprandial salivary glucose by serum glucose (patients)

\begin{tabular}{llll}
\hline $\begin{array}{l}\text { Serum glucose } \\
\text { range }\end{array}$ & $\begin{array}{l}\text { Mean of } \\
\text { salivary glucose }\end{array}$ & SD & $f$-value \\
\hline Below $130 \mathrm{mg} / \mathrm{dL}$ & $2.18 \mathrm{mg} / \mathrm{dL}$ & 1.29 & $42.13^{* *}$ \\
I $30-200 \mathrm{mg} / \mathrm{dL}$ & $4.05 \mathrm{mg} / \mathrm{dL}$ & 2.56 & $(P<0.01)$ \\
Above $200 \mathrm{mg} / \mathrm{dL}$ & $8.74 \mathrm{mg} / \mathrm{dL}$ & 4.50 & \\
\hline
\end{tabular}

Note: **f-value shows statistically significant difference between serum glucose and salivary glucose.

Abbreviation: SD, standard deviation.

age groups of patients. Similarly, no significant differences were found when salivary glucose was compared between male and female patients, using an independent $t$-test $(P>0.05)$.

\section{Discussion}

Diabetes mellitus is a group of metabolic disorders that share the common underlying feature of hyperglycemia. Hyperglycemia in diabetes results from defects in insulin secretion, insulin action, or, most commonly, both. Chronic hyperglycemia and the attendant metabolic dysregulation may be associated with secondary damage in multiple organ systems, especially the kidneys, eyes, nerves, and blood vessels. ${ }^{6}$

Data indicates that in 2011, 366 million people worldwide were affected by diabetes and the number is continuing to climb steeply. ${ }^{7}$ By 2030 , predictions suggest that the number of people with diabetes will reach 552 million. Currently, India is in the second position in the chart, after the People's Republic of China. ${ }^{7}$

Currently, a diagnosis of diabetes is achieved only by analyzing blood glucose levels (random, fasting, and postprandial), ${ }^{8}$ which are invasive methods that are physically and psychologically traumatic to the patient. Therefore, a noninvasive, simple, and painless procedure, such as salivary glucose estimation, is very desirable.

In our study, we found that fasting salivary glucose values were higher among diabetics than in the controls; the difference was statistically highly significant $(P<0.01)$. Fleckseder and Carlson and Ryan ${ }^{9}$ reported the presence

Table 3 Comparison of preprandial salivary glucose by glycated hemoglobin $\left(\mathrm{HbA}_{\mathrm{lc}}\right)$

\begin{tabular}{llll}
\hline HBA $_{\text {IC }}$ range & Mean & SD & $f$-value \\
\hline Up to $7 \%$ & $2.30 \mathrm{mg} / \mathrm{dL}$ & $\mathrm{I} .34$ & $\mathrm{I} 5.80^{* *}$ \\
$7 \%-8 \%$ & $3.8 \mathrm{Img} / \mathrm{dL}$ & 3.12 & $(P<0.0 \mathrm{I})$ \\
Over $8 \%$ & $6.72 \mathrm{mg} / \mathrm{dL}$ & 4.64 &
\end{tabular}

Note: **f-value shows statistically significant difference between preprandial salivary glucose and glycated hemoglobin.

Abbreviation: SD, standard deviation. of sugar in the saliva of diabetic patients and other authors have reported increases in salivary glucose levels in diabetes mellitus patients in comparison to nondiabetics. ${ }^{10-21}$ However, Forbat et $\mathrm{a}^{22}$ concluded that salivary glucose levels did not reflect blood glucose levels. Similarly, Carda et al ${ }^{23}$ concluded that the salivary glucose levels of $76.4 \%$ of diabetic patients were in the normal range.

In the present study, there was a positive correlation between salivary and serum glucose in diabetic patients. A correlation between salivary and serum glucose was found in the controls as well. These correlations were found to be statistically significant. Hence, salivary glucose appears to be an indicator of serum glucose concentration in diabetic patients. Similar to our study, five studies ${ }^{11,15,17,20,21}$ found a positive correlation between salivary glucose and serum glucose. However, in contrast to our study, three other trials ${ }^{12,22,23}$ could not establish a correlation between salivary and serum glucose. Even Englander et $\mathrm{al}^{10}$ expressed doubt regarding replacement of plasma with parotid secretion in the diagnosis of diabetes mellitus, because of its lower levels of glucose concentration. However, Mitsumori et $\mathrm{al}^{5}$ manufactured a saliva analyzing system using a glucose sensor and performed in vivo evaluations, concluding that their salivary glucose level measurement system could be used as an indicator of blood glucose level.

We also estimated the $\mathrm{HbA}_{1 \mathrm{c}}$ levels in diabetic patients and found a positive correlation between $\mathrm{HbA}_{1 \mathrm{c}}$ percentage and salivary glucose level. The value was statistically significant. In contrast to our study, Lopez et $\mathrm{al}^{18}$ did not find any correlation between salivary glucose level and $\mathrm{HbA}_{1 \mathrm{c}}$ percentage. We divided the patient group into three subgroups based on their serum glucose level and compared the salivary glucose levels of those three groups. We found a statistically significant difference among the three groups, and the salivary glucose levels were found to increase as serum glucose levels increased. We found that patients with serum glucose levels below $130 \mathrm{mg} / \mathrm{dL}$ showed a mean salivary glucose level of $2.18 \mathrm{mg} / \mathrm{dL}$. Patients with serum glucose levels between 130 and $200 \mathrm{mg} / \mathrm{dL}$ showed a mean salivary glucose level of $4.05 \mathrm{mg} / \mathrm{dL}$ and patients with serum glucose levels above $200 \mathrm{mg} / \mathrm{dL}$ reflected a mean salivary glucose level of $8.74 \mathrm{mg} / \mathrm{dL}$. As such, we are tempted to say that patients with salivary glucose levels above $4 \mathrm{mg} / \mathrm{dL}$ have a very high chance of having serum glucose levels above $130 \mathrm{mg} / \mathrm{dL}$.

Similarly, we divided the patient group into three subgroups based on their $\mathrm{HbA}_{1 \mathrm{c}}$ percentage. Patients with $\mathrm{HbA}_{1 \mathrm{c}} \leq 7 \%$ 
were considered ideal control level, 7\%-8\% were considered reasonable control, and $>8 \%$ were considered poor control. ${ }^{24}$ When we compared salivary glucose levels across the three subgroups, we found a statistically significant difference between them. Here, also, an increase in the salivary glucose level was noticed with an increase in $\mathrm{HbA}_{1 \mathrm{c}}$ percentage. The ideal level control showed a mean salivary glucose level of $2.30 \mathrm{mg} / \mathrm{dL}$, the reasonable control showed $3.81 \mathrm{mg} / \mathrm{dL}$, and the poor control showed $6.72 \mathrm{mg} / \mathrm{dL}$. We found that poor glycemic control leads to a high salivary glucose level, hence, this points toward the poor glycemic control achieved in the patient. These results were similar to our earlier results based on serum glucose levels.

We know that glucose is present in the saliva of normal individuals; however, the mechanism of its secretion is still obscure. Both paracellular and intercellular pathways have been proposed, ${ }^{25}$ but this is still an hypothesis rather than an established theory. Many authors have tried to explain the increased glucose content in the salivary secretion of diabetic patients. Lopez et al ${ }^{18}$ tried to show that the salivary glands act as filters of blood glucose that are altered by hormonal or neural regulation. According to Qureshi et $\mathrm{al}^{26}$ persistent hyperglycemia leads to microvascular changes in the blood vessels, as well as basement membrane alteration in the salivary glands. This leads to increased leakage of glucose from the ductal cells of the salivary gland, thereby increasing the glucose content in saliva. Sreedevi et $\mathrm{al}^{20}$ quoting the works of Harrison, commented that glucose is a small molecule that easily diffuses through semipermeable membranes. Thus, large amounts of glucose become available to saliva when blood glucose levels are elevated, as in diabetes. Alterations in the permeability, occurring as a result of basement membrane changes in diabetes, may be an additional explanation for the increased concentration of glucose in saliva.

It is well-established that the complications of diabetes are due to microvascular changes. ${ }^{6}$ Many theories have been put forth to explain the microvascular alterations. To summarize, hyperglycemia leads to increased advanced glycosylation end products, commonly known as "AGEs". These AGEs crosslink proteins such as collagen and extracellular matrix proteins, leading to basement membrane alteration and, hence, endothelial dysfunction. This alters the microvasculature structure and makes it more permeable. Other products, such as sorbitol, diacylglycerol, and fructose-6-phosphate, which are formed because of chronic hyperglycemia, also lead to basement membrane alteration by altering the extracellular matrix proteins. The end result is a leaky microvasculature and a leaky basement membrane, ${ }^{6}$ which explains the increased passage of glucose from the blood into the saliva in diabetes mellitus.

Belazi et al ${ }^{15}$ proposed that the increased permeability of basement membrane in insulin-dependent diabetes mellitus may lead to enhanced leakage of serum-derived components into whole saliva via gingival crevices. The small glucose molecule can easily diffuse via the semipermeable basement membrane. They blamed the gingival crevicular fluid as the culprit for increased glucose levels in salivary secretion. This shows that the presence of glucose in saliva is multifactorial and no single mechanism can be blamed.

\section{Serum glucose $=99.664+13.027$ salivary glucose}



Figure I Correlation between preprandial salivary and serum glucose levels in the study group.

Note: Regression coefficient was calculated and a formula (shown) was derived for the prediction of serum glucose from salivary glucose in the study group. 


\section{$\mathrm{HbA}_{1 \mathrm{C}}=6.762+0.249$ salivary glucose}

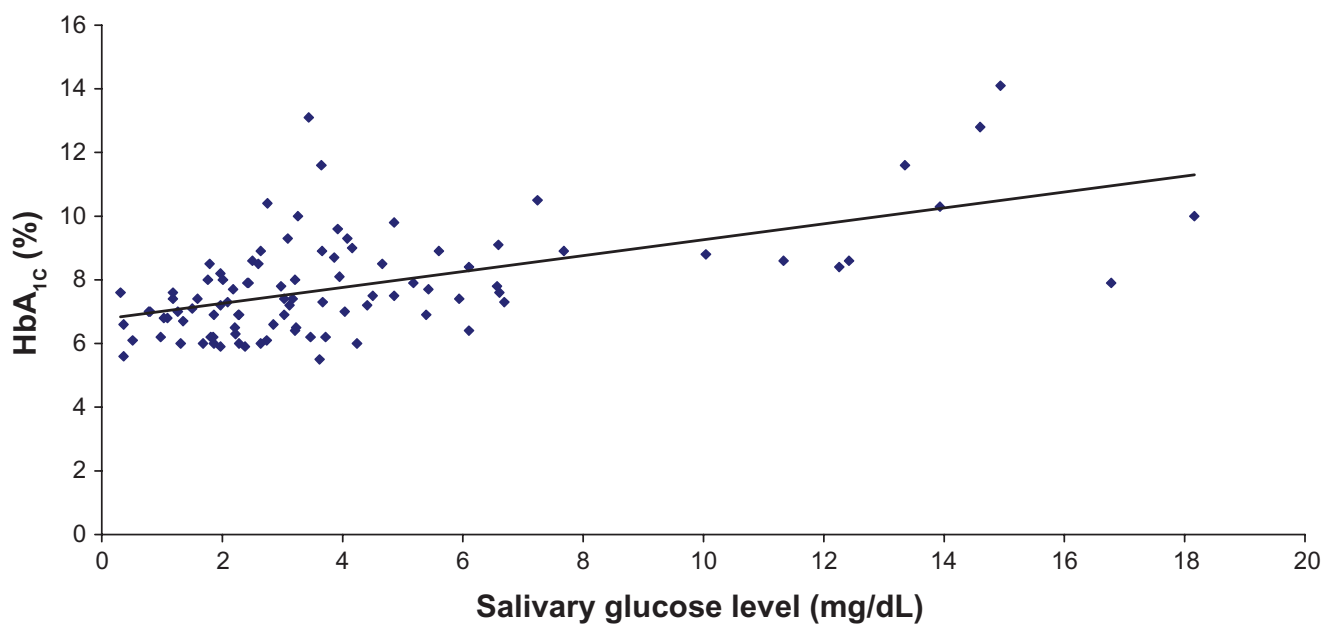

Figure 2 Correlation between preprandial salivary glucose levels and glycated hemoglobin $\left(\mathrm{HbA}_{\mid c}\right)$ percentages in the study group. Note: Regression coefficient was calculated, and a formula (shown) was derived for the prediction of $\mathrm{HbA}_{\mathrm{lc}}$ from salivary glucose in the study group.

We found a highly significant correlation coefficient between salivary glucose level and serum glucose level, as well as between salivary glucose level and $\mathrm{HbA}_{1 \mathrm{c}}$ percentage, and a regression coefficient was calculated. The regression coefficient gives the amount of increase or decrease in the serum glucose or $\mathrm{HbA}_{1 \mathrm{c}}$ for a unit change in the salivary glucose. Hence, from a given value of salivary glucose, we can predict serum glucose level and $\mathrm{HbA}_{1 \mathrm{c}}$ percentage by using the regression equation (Figures 1 and 2).

The respective formulas are:

Serum glucose $=99.664+13.027$ salivary glucose (patient) $\mathrm{HbA}_{1 \mathrm{c}}=6.762+0.249$ salivary glucose (patient)

We found increased fasting salivary glucose levels in patients suffering from diabetes mellitus. We also formulated equations to predict the fasting serum glucose level and $\mathrm{HbA}_{1 \mathrm{c}}$ percentage when the fasting salivary glucose level is known. Therefore, it can be concluded that fasting salivary glucose level can be used as a noninvasive diagnostic, as well as a monitoring tool to assess the glycemic status of diabetes mellitus patients. Nevertheless, further studies on larger populations and in different geographic areas are needed to establish salivary glucose estimation as a diagnostic as well as a monitoring tool for diabetes mellitus.

\section{Disclosure}

The authors report no conflicts of interest in this work.

\section{References}

1. Little RR, Goldstein DE. Endocrine (standardization of glycohemoglobin measurement). Anal chem. 1995;67(12):393R-397R.
2. World Health Organization, International Diabetes Federation. Diabetes Action Now. Geneva: World Health Organization; 2004. Available from: http://www.who.int/entity/diabetes/actionnow/en/DANbooklet.pdf. Accessed August 12, 2008.

3. Peterson KP, Pavlovich JG, Goldstein D, Little R, England J, Peterson CM What is hemoglobin A1c? An analysis of glycated hemoglobins by electrospray ionization mass spectrometry. Clin Chem. 1998;44(9): 1951-1958.

4. Kilpatrick ES. Glycated haemoglobin in the year 2000. J Clin Pathol. 2000;53(5):335-339.

5. Mitsumori M, Yamaguchi M, Kano Y. A new approach to noninvasive measurement of blood glucose using saliva analyzing system. Conf Proc IEEE Eng Med Biol Soc. 1998;4:1767-1770.

6. Powers AC. Diabetes mellitus. In: Fauci A, Braunwald E, Kasper D, et al, editors. Harrison's Principles of Internal Medicine. New York: McGraw-Hill; 2008:2275-2304.

7. Idf.org [homepage on the Internet]. Brussels: International Diabetes Federation; 2011. Available from: http://www.idf.org/diabetesatlas. Accessed April 10, 2012.

8. The Expert Committee on the Diagnosis and Classification of Diabetes Mellitus. Report of the expert committee on the diagnosis and classification of diabetes mellitus. Diabetes Care. 2002;25(Suppl 1):S5-S20.

9. Carlson AJ, Ryan JG. Glucose in saliva. Am J Physiol. 1908;21: 301-309.

10. Englander HR, Jeffay AI, Fuller JB, Chauncey HH. Glucose concentrations in blood plasma and parotid saliva of individuals with and without diabetes mellitus. J Dent Res. 1963;42:1246.

11. Reuterving CO, Reuterving G, Hägg E, Ericson T. Salivary flow rate and salivary glucose concentration in patients with diabetes mellitus influence of severity of diabetes. Diabete Metab. 1987;13(4):457-462.

12. Ben-Aryeh H, Cohen M, Kanter Y, Szargel R, Laufer D. Salivary composition in diabetic patients. J Diabet Complications. 1988;2(2): 96-99.

13. Thorstensson H, Falk H, Hugoson A, Olsson J. Some salivary factors in insulin-dependent diabetics. Acta Odontol Scand. 1989;47(3): $175-183$.

14. Darwazeh AM, MacFarlane TW, McCuish A, Lamey PJ. Mixed salivary glucose levels and candidal carriage in patients with diabetes mellitus. J Oral Pathol Med. 1991;20(6):280-283.

15. Belazi MA, Galli-Tsinopoulou A, Drakoulakos D, Fleva A, Papanayiotou $\mathrm{PH}$. Salivary alterations in insulin-dependent diabetes mellitus. Int $J$ Paediatr Dent. 1998;8(1):29-33. 
16. Borg Andersson A, Birkhed D, Berntorp K, Lindgärde F, Matsson L. Glucose concentration in parotid saliva after glucose/food intake in individuals with glucose intolerance and diabetes mellitus. Eur J Oral Sci. 1998;106(5):931-937.

17. Amer S, Yousuf M, Siddqiui PQ, Alam J. Salivary glucose concentrations in patients with diabetes mellitus - a minimally invasive technique for monitoring blood glucose levels. Pak J Pharm Sci. 2001;14(1): 33-37.

18. Lopez ME, Colloca ME, Paez RG, Schallmach JN, Koss MA, Chervonagura A. Salivary characteristics of diabetic children; Braz Dent J. 2003;14(1):26-31.

19. Aydin S. A comparison of gherlin, glucose, alpha-amylase and protein levels in saliva from diabetics. J Biochem Mol Biol. 2007;40(1): 29-35.

20. Sreedevi, Shashikanth MC, Shambulingappa P. Comparison of serum glucose and salivary glucose in diabetic patients. Journal of Indian Academy of Oral Medicine and Radiology. 2008;20(1):9-13.

21. Jurysta C, Bulur N, Oguzhan B, et al. Salivary glucose concentration and excretion in normal and diabetic subjects. J Biomed Biotechnol. 2009;2009:430426.
22. Forbat LN, Collins RE, Maskell GK, Sönksen PH. Glucose concentrations in parotid fluid and venous blood of patients attending a diabetic clinic. J R Soc Med. 1981;74(10):725-728.

23. Carda C, Mosquera-Lloreda N, Salom L, Gomez de Ferraris ME, Peydró A. Structural and functional salivary disorders in type 2 diabetic patients. Med Oral Patol Oral Cir Bucal. 2006;11(4):E309-E314. English and Spanish.

24. Jayaram BM. Type 2 diabetes and its complications: a preventive program. 1st ed. Bangalore: Micro Labs; 2008.

25. Takai N, Yoshida Y, Kakudo Y. Secretion and re-absorption of glucose in rat submandibular and sublingual saliva. J Dent Res. 1983;62(10): 1022-1025.

26. Qureshi A, Qureshi A, Qureshi H, Khan AA. Blood glucose level, salivary $\mathrm{pH}$ and oral bacterial count in type 1 diabetic children. Infect Dis J. 2007;16(2):45-48.

\section{Publish your work in this journal}

Diabetes, Metabolic Syndrome and Obesity: Targets and Therapy is an international, peer-reviewed open-access journal committed to the rapid publication of the latest laboratory and clinical findings in the fields of diabetes, metabolic syndrome and obesity research. Original research, review, case reports, hypothesis formation, expert opinion and commentaries are all considered for publication. The manuscript management system is completely online and includes a very quick and fair peer-review system, which is all easy to use. Visit http://www.dovepress.com/testimonials.php to read real quotes from published authors.

Submit your manuscript here: http://www.dovepress.com/diabetes-metabolic-syndrome-and-obesity-targets-and-therapy-journal 